\title{
A short comparative history of wells and toilets in South Africa and Finland
}

\author{
Johannes HaArhoff, Petri JuUti and Harri MäKI*
}

\begin{abstract}
This paper describes the technological development of wells and toilets and the cultural practices related to them in two countries, South Africa and Finland, from the Middle Ages to modern times. Wells and toilets have always been linked to the well-being of humans and they still are the most common technical systems in the service of mankind. They are simple to build, but if they are constructed improperly or stop functioning properly, they may endanger the health of both humans and the environment. The solutions used for getting clean water or for disposal of excrement have always been a matter of life and death for human settlements. Located on opposite sides of the world, the climate and natural resources of South Africa and Finland are very different. However, surprisingly similar solutions, for example wind turbines to pump water, have been used in rural areas. Furthermore, urbanization and industrialization occurred in both countries at approximately the same time in the 19th century, which caused increasing environmental problems in Finnish and South African urban areas. The transition to modern water supply and waste disposal systems was a very demanding process for municipal administrations in both countries.
\end{abstract}

Key words: Urban environment, wells, toilets, environmental history, South Africa, Finland

Although South Africa and Finland, as a result of their respective geographic localities, appear to share little in common, there are, surprisingly enough, some interesting similarities. Both are countries with climatic extremes; South Africa with its aridity and heat; and Finland with its extreme arctic conditions. In a way, these extremes are comparable in terms of human sustenance. The most arid province in South Africa (the Northern Cape) and the northernmost province of Finland (Lapland) both cover 30 per cent of the surface area of their respective countries and both have an extremely low population density of 2 persons per square kilometre (Table 1). However, there

* Johannes Haarhoff is Professor of civil engineering at the University of Johannesburg; South Africa. Petri Juuti is adjunct Professor of History at the University of Tampere, Finland. Harri Mäki is a doctoral student at the University of Tampere, Finland. 
are significant differences between the water resources of the two countries (Table 2).

\begin{tabular}{|l|c|c|c|}
\hline Province & $\begin{array}{c}\text { Population } \\
\text { (million) }\end{array}$ & $\begin{array}{c}\text { Area } \\
\left(\mathrm{km}^{2}\right)\end{array}$ & $\begin{array}{c}\text { Density } \\
\left(\# / \mathrm{km}^{2}\right)\end{array}$ \\
\hline Northern Cape & 0.823 & 361830 & 2 \\
Free State & 2.707 & 129480 & 21 \\
North-West & 3.669 & 116320 & 32 \\
Western Cape & 4.524 & 129370 & 35 \\
Eastern Cape & 6.437 & 169580 & 38 \\
Mpumalanga & 3.123 & 79490 & 39 \\
Limpopo & 5.274 & 123910 & 43 \\
Kwazulu-Natal & 9.426 & 92100 & 102 \\
Gauteng & 8.837 & 17010 & 520 \\
& & & \\
SOUTH AFRICA & 44.820 & 1219090 & 37 \\
\hline Lapland & 0.199 & 98946 & 7 \\
Oulu & 0.453 & 61572 & 10 \\
Eastern Finland & 0.604 & 60720 & 53 \\
Western Finland & 1.829 & 80975 & \\
Southern Finland & 2.037 & 34378 & 15 \\
& & & \\
FINLAND & 5.122 & 336591 & \\
\hline
\end{tabular}

Table 1 Comparative population density for South African and Finnish provinces ${ }^{1}$

A comparison of rainfall indicates how much water resources diverge. Finland has a fairly uniform annual rainfall distribution $(450 \mathrm{~mm}$ to 650 $\mathrm{mm}$ ) whereas the annual rainfall in South Africa varies between less than $100 \mathrm{~mm}$ to more than $2000 \mathrm{~mm}$. A large part of South Africa is considered to be arid (21 per cent has less than $200 \mathrm{~mm}$ annual rainfall) or semi-arid (44 per cent receives between 200 and $500 \mathrm{~mm} /$ year). Therefore some 65 per cent of the country does not receive enough rainfall for successful dryland farming. In Finland a much higher percentage of rainfall (55 per cent as opposed to 7 per cent) appears as surface runoff after evaporation and infiltration, consequently leaving Finland richly endowed with natural lakes and streams. There are approximately 56000 lakes larger than $1 \mathrm{~km}^{2}$ and the total number of all water bodies, such as rivers and lakes, is approximately 188000 (Honkavirta 1998, 62; Myllyntaus 2004, 11-12; Pajula \& Triipponen 2003, 9-10; Haarhoff \& Tempelhoff 2004). In terms of renewable water resources, South Africa has only 45 per cent of the water of Finland, despite being four times larger. When factoring in the respective populations, Finland has 18 times more water available per capita than South Africa.

1 From www.statoids.com, accessed on May 1, 2005. Note that there are small differences in population numbers and land areas when compared to Table 1, which do not impact on the general trends demonstrated. 
It is hardly surprising that South Africa is already exploiting a significant part of its total water resources. In the important Vaal River catchment area, which supplies the heartland of South Africa's manufacturing, mining and power industries, the critical limits of the natural run-off had been reached already in the 1980s and thus massive interbasin transfer schemes from other regions in South Africa, as well as from the neighbouring country of Lesotho, had to be implemented (Haarhoff \& Tempelhoff 2004). While South Africa is already exploiting a massive 32 per cent of the theoretical maximum of its water resources, Finland uses only of 2.1 per cent of its theoretical maximum.

\begin{tabular}{|c|c|c|c|}
\hline & SA & FINLAND & SA / FIN \\
\hline $\begin{array}{l}\text { POPULATION DENSITY } \\
\text { a Surface area }\left(\mathrm{km}^{2}\right) \\
\text { a Population (million) } \\
\text { a Population density }\left(\# / \mathrm{km}^{2}\right)\end{array}$ & $\begin{array}{c}1221040 \\
43.309 \\
35\end{array}$ & $\begin{array}{c}304590 \\
5.172 \\
17\end{array}$ & $\begin{array}{l}4.01 \\
8.37 \\
2.09\end{array}$ \\
\hline $\begin{array}{l}\text { WATER RESOURCES } \\
\text { h Rainfall, including snow }(\mathrm{mm}) \\
\text { b Runoff }(\mathrm{mm}) \\
{ }^{\mathrm{b}} \text { Percentage runoff } \\
{ }^{\text {a }} \text { Total water availability }\left(\mathrm{km}^{3} / \mathrm{a}\right)\end{array}$ & $\begin{array}{c}475 \\
35 \\
7 \% \\
45\end{array}$ & $\begin{array}{c}575 \\
318 \\
55 \% \\
107\end{array}$ & $\begin{array}{c}0.83 \\
0.10 \\
- \\
0.45\end{array}$ \\
\hline $\begin{array}{l}\text { PER CAPITA WATER AVAILABILITY } \\
\text { h Groundwater availability }\left(\mathrm{m}^{3} / \mathrm{a}\right) \\
{ }^{\mathrm{b}} \text { Surface water availability }\left(\mathrm{m}^{3} / \mathrm{a}\right) \\
{ }^{\text {a }} \text { Total water availability }\left(\mathrm{m}^{3} / \mathrm{a}\right)\end{array}$ & $\begin{array}{c}112 \\
1042 \\
1154\end{array}$ & $\begin{array}{c}366 \\
20902 \\
21268\end{array}$ & $\begin{array}{l}0.31 \\
0.05 \\
0.05\end{array}$ \\
\hline $\begin{array}{l}\text { PER CAPITA WATER USE } \\
\text { h Groundwater use }\left(\mathrm{m}^{3} / \mathrm{a}\right) \\
{ }^{\mathrm{b}} \text { Surface water use }\left(\mathrm{m}^{3} / \mathrm{a}\right) \\
{ }^{\mathrm{c}} \text { Total water use }\left(\mathrm{m}^{3} / \mathrm{a}\right)\end{array}$ & $\begin{array}{c}(2000) \\
67 \\
299 \\
366\end{array}$ & $\begin{array}{c}(1995) \\
39 \\
400 \\
439\end{array}$ & $\begin{array}{l}1.72 \\
0.75 \\
0.83\end{array}$ \\
\hline $\begin{array}{l}\text { RESOURCE EXPLOITATION } \\
\text { b Groundwater exploitation } \\
\text { b Surface water exploitation } \\
\text { b Total water exploitation }\end{array}$ & $\begin{array}{l}(2000) \\
59.8 \% \\
28.7 \% \\
31.7 \%\end{array}$ & $\begin{array}{c}(1995) \\
10.7 \% \\
1.9 \% \\
2.1 \%\end{array}$ & $\begin{array}{l}- \\
- \\
-\end{array}$ \\
\hline $\begin{array}{l}\text { WATER USE } \\
\text { Percentage domestic use } \\
\text { Percentage industrial use } \\
\text { Percentage agricultural use }\end{array}$ & $\begin{array}{l}\text { d }(2000) \\
\text { e } 14 \% \\
\text { f } 21 \% \\
\text { g } 65 \%\end{array}$ & $\begin{array}{c}\mathrm{c}(1991) \\
12 \% \\
85 \% \\
3 \%\end{array}$ & $\begin{array}{l}- \\
- \\
-\end{array}$ \\
\hline
\end{tabular}

Table 2 Statistical comparison between South Africa and Finland. 


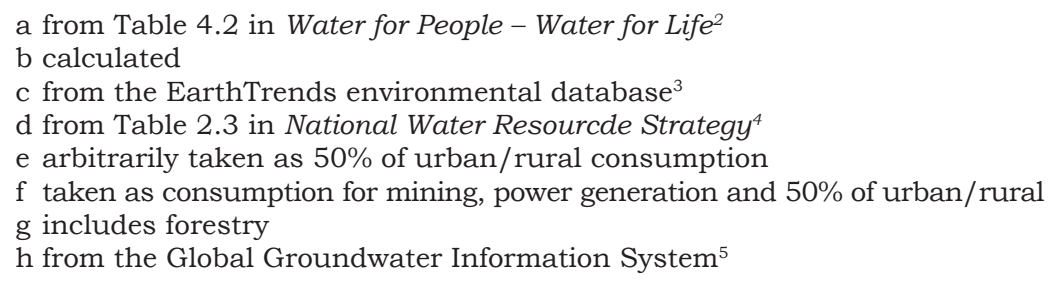

In the context of this study, it is more instructive to view groundwater resources separately from surface water resources. In both countries, the renewal rate for groundwater is much lower than for surface water, but the relative exploitation of groundwater resources is higher. In South Africa, the exploitation rates for groundwater and surface water are 60 per cent and 29 per cent of the sustainable maximum respectively, while the same rates for Finland are 11 per cent and 2 per cent. In South Africa, about 20 per cent of all water is derived from groundwater. In Finland, about 60 per cent of the potable water supplied is derived from groundwater. Wells and boreholes form the backbone of rural water supply in both countries; there are about 600000 wells in Finland serving single households or holiday homes (Salonen 2002) and more than 225000 boreholes in the national South African groundwater database, which only reflects a part of the total. Two-thirds of South Africa's surface area is depends primarily on groundwater due to the lack of perennial streams. (http://www. dwaf.gov.za/Geohydrology/Databases/databases. htm) Groundwater is therefore of indisputable importance to both countries.

The efficiency of national water management practices is measured by the Water Poverty Index (WPI). The WPI incorporates the following aspects:

- Water resources available to the population

- Access of the population to water supply and sanitation

- Capacity (in terms on income and development) of the population to exploit the available water resources

- Efficiency of water use

- Environmental aspects such as water quality, pollution and biodiversity (Lawrence \& Co. 2003).

The WPI evaluated 147 countries, and the relative position of South Africa and Finland in the different categories is shown in Table 3. Finland was ranked highest in WPI, while South Africa is in the bottom third of the countries included. A closer look at the WPI components, however,

2 Published by UNESCO (March 2003). Accessed on May 1, 2005 at http://www.unesco. org/water/wwap/wwdr/table_contents.shtml

3 Published by the World Resources Institute. Accessed on May 1, 2005 at http:// earthtrends.wri.org/country_profiles/index.cfm?theme $=2$

4 Published by Department of Water Affairs (September 2004). Accessed on May 2, 2005 at http://www.dwaf.gov.za/Documents/Policies/NWRS/Sep2004/pdf/ Chapter2.pdf

5 Published by the International Groundwater Assessment Centre. Accessed at http:// igrac.nitg.tno.nl/system.html 
reveals that in terms of their natural water availability (which they really cannot do anything about) neither score that well, but their best ranking is in the environmental category, with South Africa at position 36 and Finland in position 1. All in all, the index reveals that the level of water management in Finland is excellent and fairly good in South Africa, given geographical and developmental constraints.

\begin{tabular}{|l|c|c|}
\cline { 2 - 3 } \multicolumn{1}{c|}{} & South Africa & Finland \\
\hline Resources & 126 & 34 \\
Access & 86 & 6 \\
Capacity & 95 & 13 \\
Use & 72 & 57 \\
Environment & 36 & 1 \\
\hline Overall WPI & 103 & 1 \\
\hline
\end{tabular}

Table 3 The Water Poverty Index, as calculated for South Africa and Finland. All the values reported are the ranking of the 147 countries included in the survey, with 1 being the country with the highest score and 147 the country with the lowest score.

This article focuses in particular on two aspects of water management, wells and toilets, comparing the early experiences of both countries.

Wells in the countryside

The earliest sites where a safe supply of water was found were springs and freshwater streams such as small creeks. Not just humans, but also other mammals prefer flowing water and some even dig their own water holes - for example, elephants dig quite deep well-like holes in dry areas. On average an elephant needs to drink approximately 160 litres per day $(\ell \mathrm{p} / \mathrm{d})$; therefore the need for an adequate water source is obvious. The pit well, a simple deep water hole without any fortified walls, is the forerunner of the dug well. Water was taken from this sort of well by whatever means were available, usually just using simple vessels. One possibility was to form a chain of water carriers - this enabled the drawing of water from deep underground without advanced technology. In this way it was possible to reach water lying tens of metres deep, but then it was also necessary to get air down to those who were at the lowest level lifting the water. Water has been lifted from the dug well using the means available at the time, first with a bucket or a similar vessel, or possibly with the help of a rope or other tools. Different types of wells are described in Table 4. 


\begin{tabular}{|l|l|}
\hline \multicolumn{1}{|c|}{ Type of well } & \multicolumn{1}{c|}{ Techincal realization } \\
\hline $\begin{array}{c}\text { I Natural spring } \\
\text { \& bottomless } \\
\text { barrel in spring }\end{array}$ & no construction or very simple construction \\
\hline II Pit well & pit in the ground, no construction or very simple construction \\
\hline III Dug well & $\begin{array}{l}\text { place and construction planned, built shaft, place carefully chosen } \\
\text { by observing terrain }\end{array}$ \\
\hline IV Tube well & $\begin{array}{l}\text { pipe is pushed into the ground, place and construction planned, } \\
\text { requires precise knowledge of ground water location }\end{array}$ \\
\hline V Drill well & $\begin{array}{l}\text { pipe is drilled on rock foundation, place and construction planned, } \\
\text { requires precise knowledge of ground water location }\end{array}$ \\
\hline
\end{tabular}

\section{Table 4 Wells by their technical realization (Categorization P. Juuti).}

By approximately $3000 \mathrm{BC}$, the draw well with a counterpoise lift was invented in Babylonia and it was for over 2000 years the common and effective means to draw water. In Egypt it was called a shaduf and was used to lift water from rivers. Traditionally a draw well was built from wood, but some iron fortification might also have been used. However, the column, the counterpoise lift, the bucket pole and the bucket were wooden. If there was a need for a counterweight for the bucket, it was usually made of a heavier material. A windlass or winch was used when the well was very deep whereas the counterpoise lift was mainly used for shallower draw wells. They were followed by wind turbines, crank reels and hand pumps. The first tube wells in Finland were built at the end of the 19th century. Gradually the counterpoise lift and wind turbines were replaced by the electric pump or the drilled well. (Juuti \& Wallenius 2005, 19) (See also Table 5)

\begin{tabular}{|l|l|}
\hline \multicolumn{1}{|c|}{ Type of well } & \multicolumn{1}{c|}{ Method of lifting chronological order } \\
\hline $\begin{array}{l}\text { I Natural spring \& bottomless } \\
\text { barrel in spring }\end{array}$ & Hand, scoop, bucket \\
\hline II Pit well & Hand, scoop, bucket \\
\hline III Dug well & couwell \& rope, bucket pole, hand pump \\
\hline VI Draw well counterpoise lift & counterweight \\
\hline V Windlass well & whinch or reel \\
\hline VI Tube \& drill well & pressure of the groundwater formation or pump \\
\hline VII Wells with wind engine & wind power, rotor \\
\hline VIII Wells operated with engine & combustion engine, electricity \\
\hline
\end{tabular}

Table 5 Wells by method of lifting water (Categorization P. Juuti). 
In the countryside, watering livestock formed the major part of the water consumption. Thus, if possible, the well was placed closer to the cowshed than the house itself - humans need only a few litres of water to drink per day. According to estimates made by the Finnish Committee for household efficiency, the distance between the cowshed and the well was nevertheless approximately $50 \mathrm{~m}$ in the 1930s. Likewise the sauna (the Finnish washing place), was often placed close to the well to ease the burden of carrying water. A study by the Finnish Ministry of Agriculture shows that wells were the most common source of water in the countryside in the early 1950s and that only seven per cent of the households were connected to a water supply pipe. The most commonly used methods to draw water were a bucket, a hand pump and a winch (Katko 1988, 8-11; Paulaharju 1958, 32-33; Paulaharju 1906, 7).

The early indigenous nomads of South Africa had no need to construct elaborate water supply systems. When the very dry areas of the Northern Cape Province had good rains and vegetation the nomads moved in, and left when the drier seasons arrived. From the eighteenth century, white colonist farmers copied this practice, with a large-scale "trek" every year with their cattle and sheep to follow the available water and vegetation. Water was taken from surface depressions and streams immediately following the rains and from shallow dug wells in river-beds for the weeks following. As communities settled, the need for permanent water supplies became essential. For the very dry regions, however, the digging of a permanent well represented a large investment in time and effort, which would require land tenure and secure ownership. Where farmers could get their title to the farmland, the water supply systems were developed from the eighteenth century. In some of the very dry regions, the land stayed under government control as the so-called "crown lands" and here the water supplies were not developed until as late as the early twentieth century, when the farms were eventually sold to individual owners (Van der Merwe, 1945a, 209).

The digging of wells required much effort to get through the hard banks of stone and rock. Besides shovels, picks and chisels, heating the rock with fire and quenching with water was an early method of getting through (Van der Waal-Braaksma \& Ferreira, 1986, 63). Later, some fairly ineffective home-made explosives were tried, but things only got better in the 1880s when the newly established South African mining industry, as a side effect, made it possible to procure dynamite. Digging the wells was slow, typically requiring about three months for well with a depth of $45 \mathrm{~m}$ - equivalent to $0.5 \mathrm{~m} \mathrm{p} / \mathrm{d}$. Getting water and other supplies from far away to the well-diggers during the many months when the wells were being dug, presented a major logistical problem. Moreover, only 20-25 per cent of the attempted wells struck water and the others had to be aborted (Van der Merwe, 1945b, 44). 


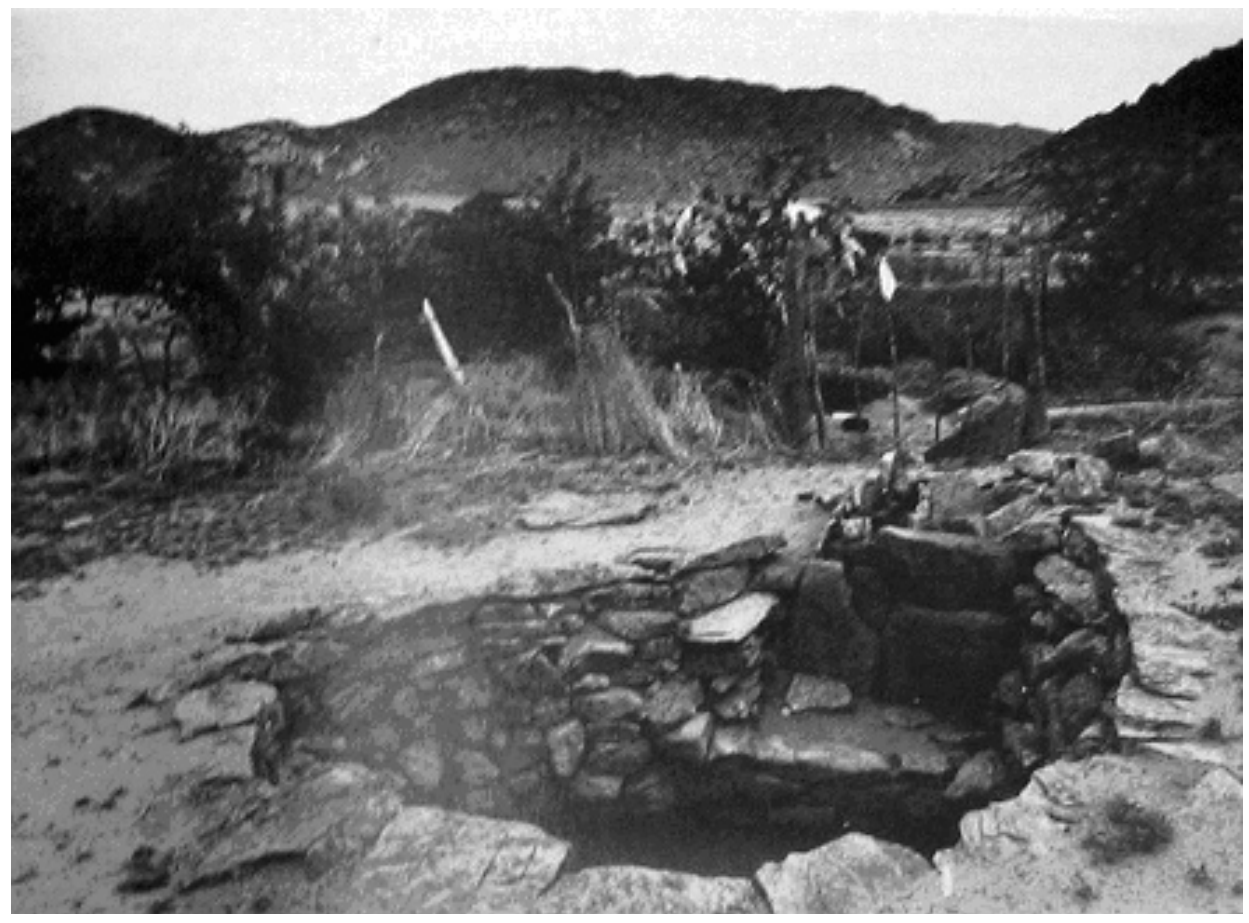

\section{Illustration 1. A typical shallow pit well in South Africa, showing the platform from which the water was drawn.}

Where the water was close to the surface, a typical well was a dug well, 2$3 \mathrm{~m}$ deep and about 5-6m in diameter, encircled by a low wall to keep the animals from the water. Inside the well, a flat stone just above the water level would serve as a small platform from where a person would scoop the water with a bucket and empty it directly into a small channel leading to a drinking-trough outside the wall, where the animals would drink (see Illustrations 1 and 2). When the well was deeper, up to about 5-10m, a lever was used, similar to the ancient Babylonian design, or a series of steps would be carved to allow the "human chain" to lift the water by progressively passing on the bucket. Deeper than this, the buckets had to be winched out with a primitive reel (see Illustration 3).

An interesting variation on this method was to use two to four donkeys on the surface to hoist the bucket by pulling the rope over the reel. By leading the donkeys away from the well, the bucket would be lifted. After the bucket had been emptied and dropped back into the well, the donkeys were brought closer to the well and the cycle was repeated. This use of animal-power allowed the use of much larger buckets of between 45 and $90 \ell$ (Van der Merwe, 1945a, 257). 


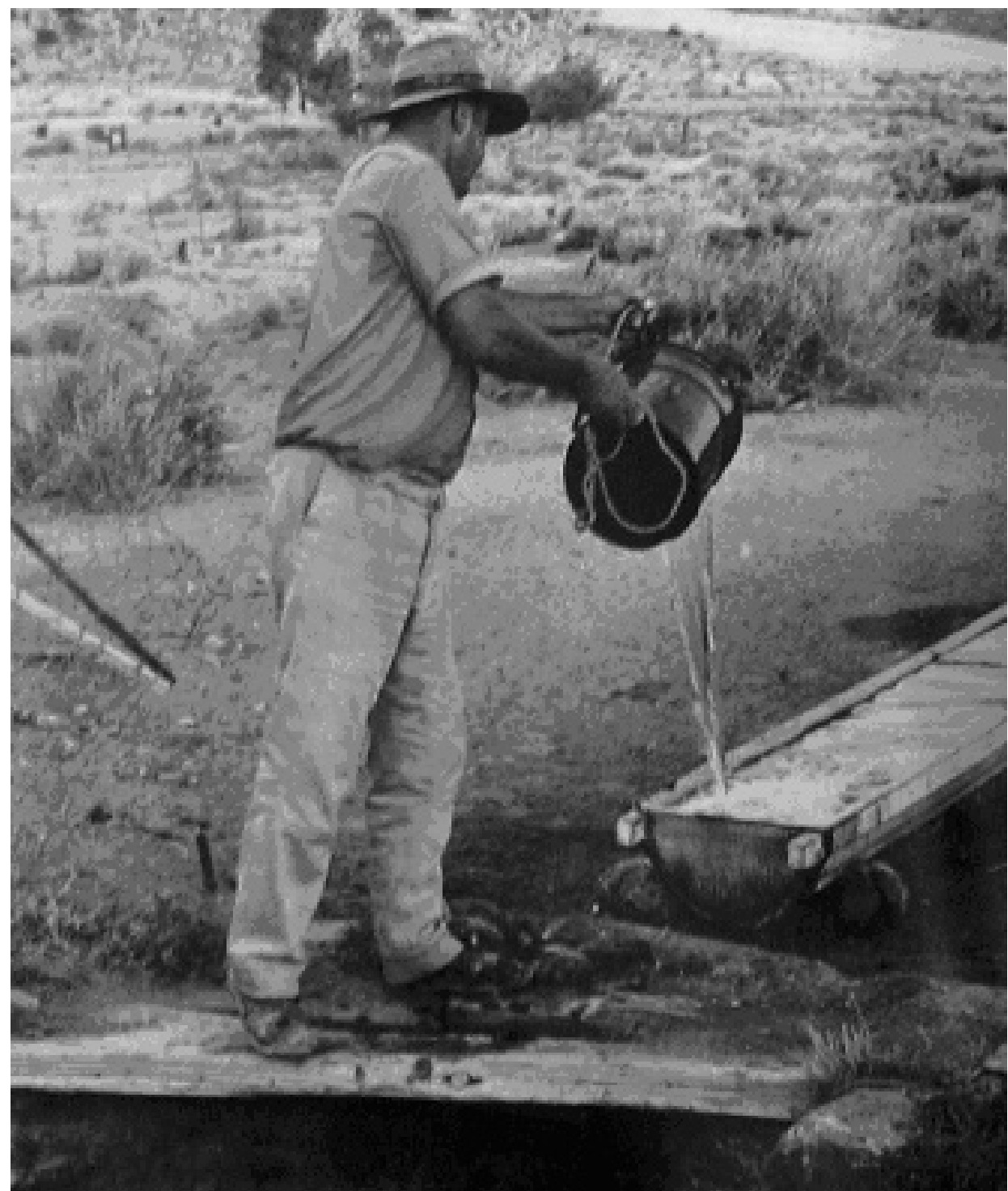

\section{Illustration 2. Water being hand drawn from a shallow pit well in South Africa, and transferred to a livestock watering trough.}

Typical of South African wells in the remote rural areas, was the reliance on hand-made equipment using local materials. Home-made explosives were packed in a bottle, provided with a fuse and sealed with beeswax. Buckets were made of canvas and water-proofed with animal fat. A circular ring was fixed to the top of the bag to keep the bucket 'open', with a second ring sometimes at the bottom. To simplify the emptying of the large buckets when the donkeys were used, a canvas spout was fixed to the bottom of the bucket, long enough to be tied to the handle 
of the bucket while it was being filled and lifted - a very simple valve! Buckets were sometime made of more durable leather and stored in the cool, moist area immediately above the water in the well to extend their lives, but only lasted eight months at the most (Van der Merwe, 1945a, 258).

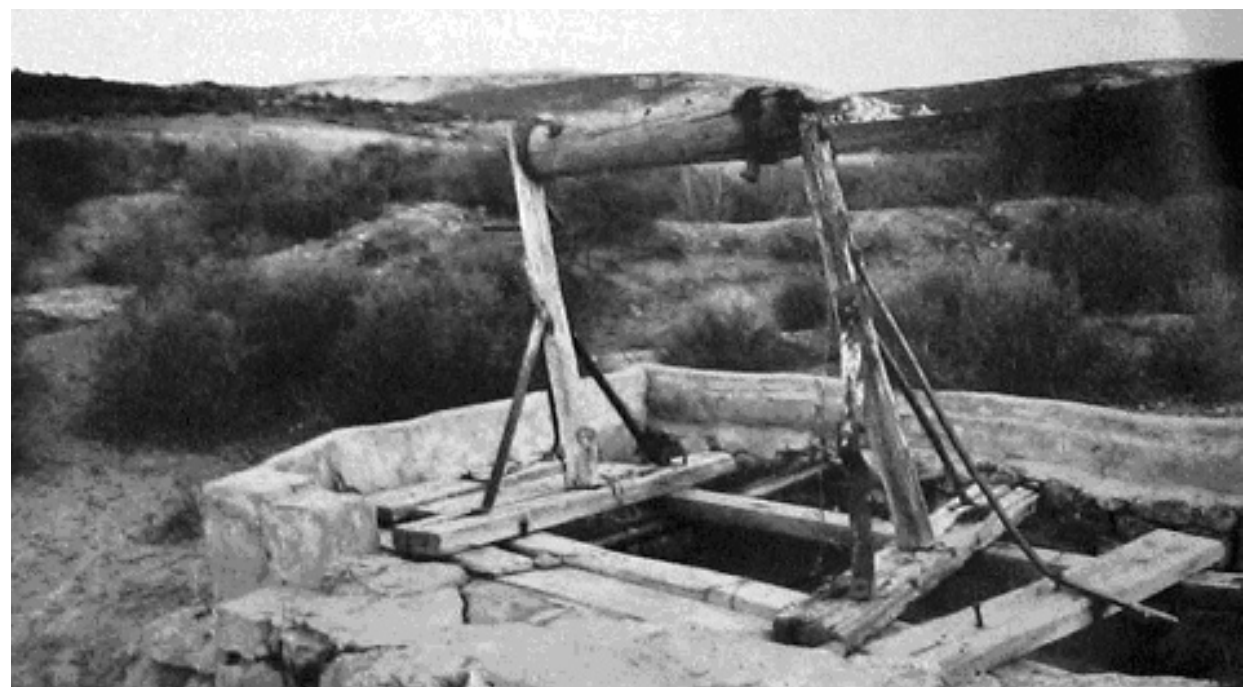

Illustration 3. A deeper well (in South Africa) with a reel, dating back to 1880 .

When a well with good water was found, special measures had to be taken to ensure that different herds of sheep could be adequately watered without getting mixed up. A simple method to extend the watering capacity was to have two or more watering-troughs extending from the same well, to allow more than one herd at the well at a time. A more elaborate arrangement was to dig more than one well close to each other, thus increasing the water production rate. The importance of such wateringpoints are reflected in the indigenous languages of South Africa - a strong water source was known as 'the womb' and an area which allowed more than one well at the same point was known as a 'stomach' (Van der Merwe, 1945b, 105, 259).

In South Africa wells with wind turbines replaced all the other types of wells outside of urban areas at the beginning of the 1870s. The first wind turbines were imported from England, America and Australia (Walton, 1954, 155). The drawn-out war between the Boer Republics and Britain, known as the Anglo Boer War (1899 and 1902) brought agricultural development to a practical standstill. In 1903, soon after the war and in the time of rebuilding the country's agricultural production capacity, a devastating drought struck South Africa. This accelerated the introduction of the wind turbine and accounted for the fact that wind turbines were recorded for the first time in 1904 by the Cape census, which reported 
that in the Cape Colony there were 1275 wind turbines and 364 water wheels in use. By 1914 there was, for example, one wind turbine for every 4000 ha in the Reddersburg district in the Free State Province. In the drier parts such as Bushmanland in the Northern Province, the development was slower and by 1945 a farmer with one wind turbine for every 5000 ha was considered to be fortunate. According to the South African agricultural census in 1926, the number of wind turbines on the country's farms was 44 000, in 1946101000 and in 1955151 000. In 1942 the first wind turbines were locally manufactured and the Climax company alone (there were others as well) had manufactured 150000 units by 1974. (Archer, 2000, 682; Walton, 1954, 155; Van der Merwe, $1945 b, 51)$. In recent times, technology has evolved further and the use of submersible pumps in boreholes and solar power spread into the Karoo (a dry area in central South Africa) during the 1980s and 1990s.

A wind turbine (Illustrations $4 a$ and $4 b$ ) is very reliable and usually requires very little maintenance. Wind power is still used on a large scale in South Africa. In 2003 there were about 300000 wind turbines on farms across South Africa, second in number only to Australia. Nowadays even in the most desolate wastelands of the Karoo, it is hard to find a place where a wind turbine cannot be seen. These turbines make many of the most arid parts of South Africa habitable. They are primarily used for watering livestock and supplying communities with water. (http:// www.africaguide.com/facts.htm, 12.5.2005; South Africa Yearbook 2003/2004, 481).

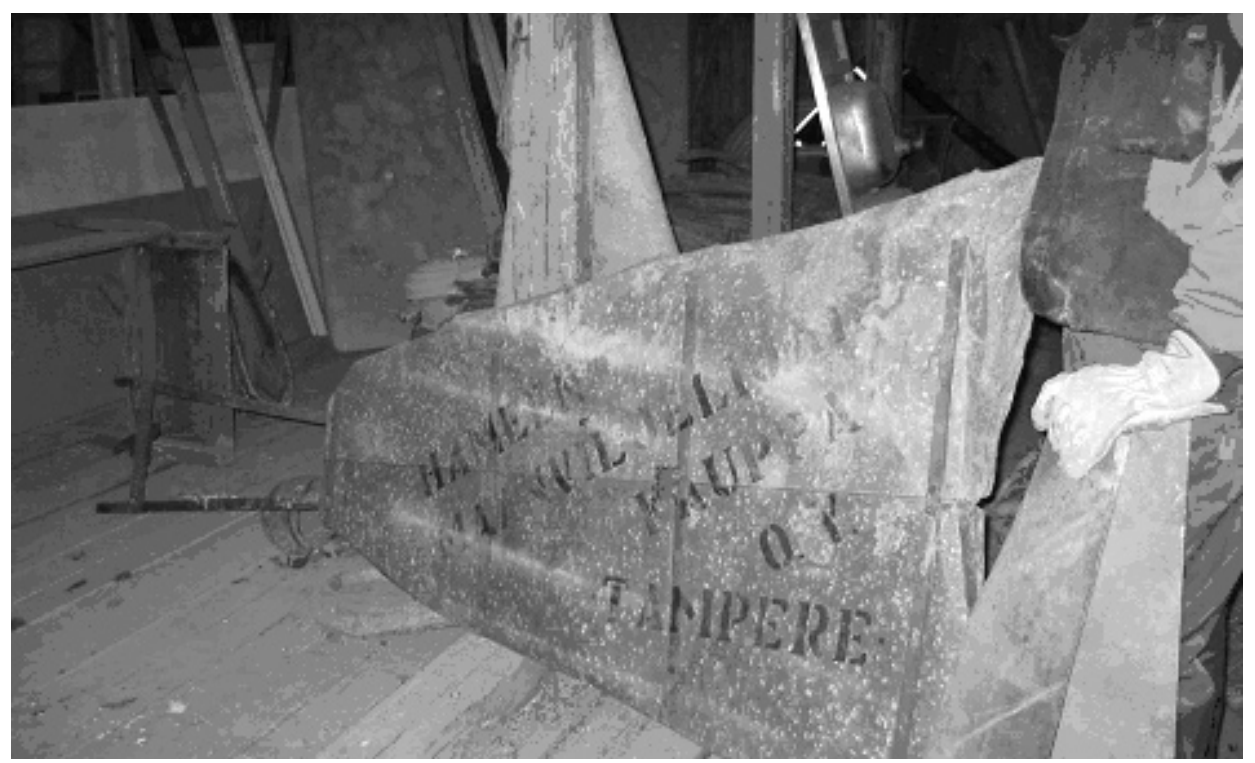

Illustration 4a Wing of wind turbine (length more than $1 \mathrm{~m}$ ), at Lihasula Estate, near Tampere. 


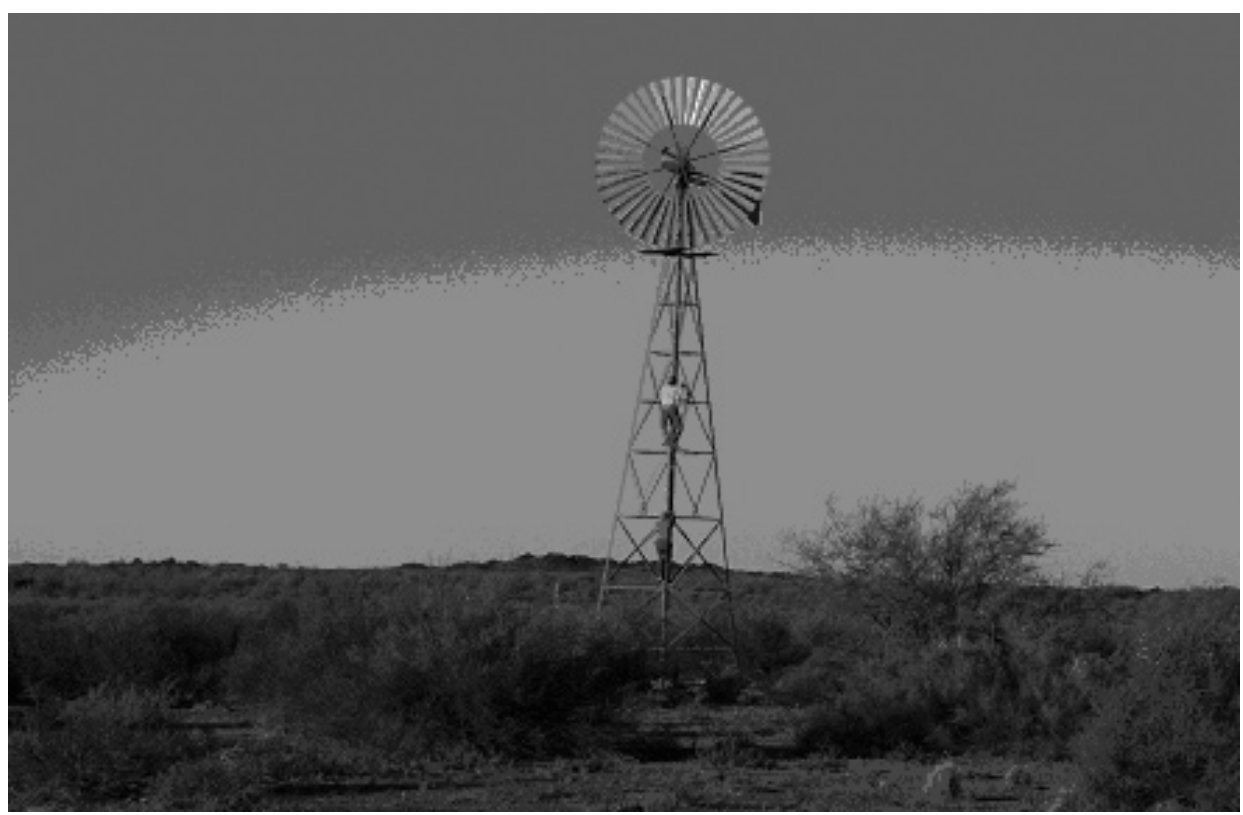

Illustration 4b A typical wind turbine in the Northwestern Cape, South Africa, on the farm Nanibees, Brandvlei District. The wind turbine, also known as a windpump in South Africa, was manufactured in the industrial city of Vereeniging in the mid-twentieth. After having fallen into disuse it was recently restored, with good effect by the owner of the farm, Mr. Francis Visagie. (Photograph: Magda Morrison (2003) with additional information by Theo Venter), Editor.

First urban wells and toilets

Compared to the rural areas with scattered settlements, castles and cities were more densely populated - the same space was sometimes shared even with a large number of livestock. Securing the water supply was of utmost importance when the layout of a castle or fortress was planned. A location near water provided a good means of transportation and on the other hand also protection against enemies. It was necessary to get water from the surroundings or preferably even inside the walls, otherwise the general safety would have been endangered significantly under siege conditions. To have a well was important also in case of fire, for it was a constant threat even in times of peace (Juuti \& Wallenius 2005, 69; about sieges: see Syvänne 2004, 295-303).

The first toilets did not require much technical construction; they were just holes in the ground. In the world today, sadly, the most common type in use is still the most primitive - a hole dug in the ground. An 
evolved, Finnish version of this latrine hole is riuku - with supporting, vertical logs on both sides of the hole and horizontal $\log (\mathrm{s})$ attached to them. It's been used widely by the Finnish army, especially during World War II, and the riuku was also introduced to later generations of young Finns doing their military service (Juuti \& Wallenius 2005, 29; Katko 1996, 96). Riuku was designed so that even several people could sit on it. A popular story from wartime Finland tells how the Soviet Red Army troops were sometimes beaten just because of the lack of good sanitation. Finns always had their riuku further away from their camps and sources of water. The Red Army was not as careful and at times the fighting condition of the troops was quite poor. There is a grain of truth in this story, for during military campaigns diseases spread among the troops with devastating results. A good example of successful maintenance is the army of the Roman Empire, which took good care to provide vital water supply and sanitation (Syvänne 2004, 104).

Upgrading doesn't always mean improving, for the most dangerous type of toilet is the "modern" water closet, which is connected to a sewer without wastewater treatment facilities. This kind of system had caused fatal epidemics and the pollution of small lakes on many occasions. An Englishman, Joseph Bramah, is usually named as the developer of the first actual water closet, in the year 1786 (Juuti 2001, 38; Wijmer 1992, 60-62).

The compost toilet is the most environmentally friendly, especially the dry compost model in which urine is collected separately. Urine diluted with water can be used as fertiliser and composted solid waste can be used for soil improvement. The amount of urine produced by one individual in a year could be used to produce $200 \mathrm{~kg}$ of grain. This method not only recycles the nutrients in the urine but it also prevents them from getting into the groundwater and watercourses. Other advantages worth mentioning are that the whole process is quite easily managed by the users themselves and the separation of urine and faeces also reduces the offensive smell. The compost toilet can thus offer a possible solution to the problem of famine often coupled with poor hygiene. It's notable that in the nineteenth century there were already dry compost and compost toilets in cities joined with different transportation systems. Choosing the water closet for the primary system in the late nineteenth and early twentieth century effectively stalled the product development of dry compost and compost toilets for over a hundred years (Mattila 2005, 41; Juuti \& Wallenius 2005, 29). (See Table 6) 


\begin{tabular}{|c|c|c|}
\hline Toilet & Method & Consequences / Results \\
\hline i Pit & none or covered with soil & waste won't compost \\
\hline $\begin{array}{l}\text { ii Outhouse } \& \text { WC, } \\
\text { no waste treatment }\end{array}$ & none & $\begin{array}{l}\text { leakage in ground or into body of } \\
\text { water, environmental hazard, wells } \\
\text { and watercourses endangered }\end{array}$ \\
\hline $\begin{array}{l}\text { iii Transportation } \\
\text { of waste within } \\
\text { organization }\end{array}$ & $\begin{array}{l}\text { centralized collection of } \\
\text { waste }\end{array}$ & depends on further treatment \\
\hline $\begin{array}{l}\text { iv WC, flush } \\
\text { water led into } \\
\text { watercourse }\end{array}$ & $\begin{array}{l}\text { waste flushed and led into } \\
\text { watercourse }\end{array}$ & $\begin{array}{l}\text { catasrophal, watercourse and in wost } \\
\text { case drinking water contaminated } \\
\text { and polluted }\end{array}$ \\
\hline $\begin{array}{l}\mathrm{v} \text { WC with } \\
\text { precipitation tank }\end{array}$ & $\begin{array}{l}\text { heavier matter sinks to the } \\
\text { bottom of the precipitation } \\
\text { tank (one or multiplepiece) }\end{array}$ & refinement only partial \\
\hline $\begin{array}{l}\text { vi WC with closed } \\
\text { wastewater tank }\end{array}$ & $\begin{array}{l}\text { waste flushed into tank, then } \\
\text { collected and transported to } \\
\text { the network of sewer works }\end{array}$ & good \\
\hline $\begin{array}{l}\text { vii WC with } \\
\text { filtering on the } \\
\text { ground }\end{array}$ & $\begin{array}{l}\text { often with the precipitation } \\
\text { tank }\end{array}$ & result varies \\
\hline $\begin{array}{l}\text { viii } \mathrm{WC} \text { and } \\
\text { treatment plant }\end{array}$ & $\begin{array}{l}\text { small local waste treatment } \\
\text { plant }\end{array}$ & result varies \\
\hline $\begin{array}{l}\text { ix WC, connected } \\
\text { to the sewer } \\
\text { network }\end{array}$ & wastewater treatment plant & $\begin{array}{l}\text { advantages of bigger units: better } \\
\text { treatment result }\end{array}$ \\
\hline $\mathrm{x}$ Compost toilet & composting & controlled recycling of units \\
\hline
\end{tabular}

Table 6 Toilets - method and consequences of treating the waste. (Categorization P. Juuti).

The oldest remaining wells and toilets are usually found in castles - both in Finland and South Africa. The castle of Good Hope in Cape Town in South Africa provided shelter and protection to soldiers and administrative staff, but it also provided good water from its wells. Cape Town was established by the Dutch in the seventeenth century and is the oldest European-style city in South Africa. It is situated by the sea and is the centre of the second largest metropolitan complex in South Africa. In the castle there is one big dug well, the so-called Kat well and a couple of smaller ones. The Kat well is, according to Werz, the oldest still remaining well in South Africa and dates back to the year 1682 (Werz 2002, 97). The Kat well had a reel and its walls were made of stone, which was a quite typical method of construction. Building this type of well requires quite good planning, expert builders and resources such as money or manpower (Juuti \& Wallenius 2005, 12-15). Originally the Kat well was built in the centre of the castle and it was about $10 \mathrm{~m}$ deep and $2 \mathrm{~m}$ in diameter. In 1691, a long building was constructed across the castle courtyard and the well was left inside, but it was still accessible to the inhabitants (Werz 2002, 95-96). Later, in the early 1700s, the Kat well 
was operated by hand pumps. Water was lifted by the pumps to an iron water tank with a capacity of about three cubic metres and from there it was distributed through pipes around the castle. Another important well was in the kitchen, equipped with a water tank and also a heating place and tap for hot water. In Cape Town fountains (Illustration 5) were erected in different parts of the town already in 1699, for slaves to draw water for their masters (Report on Cape Town Water Supply by Chas. R Barlow, October 1914, 3/CT, 4/1/1/90, ref F134/4, in Cape Town Archives Depot).

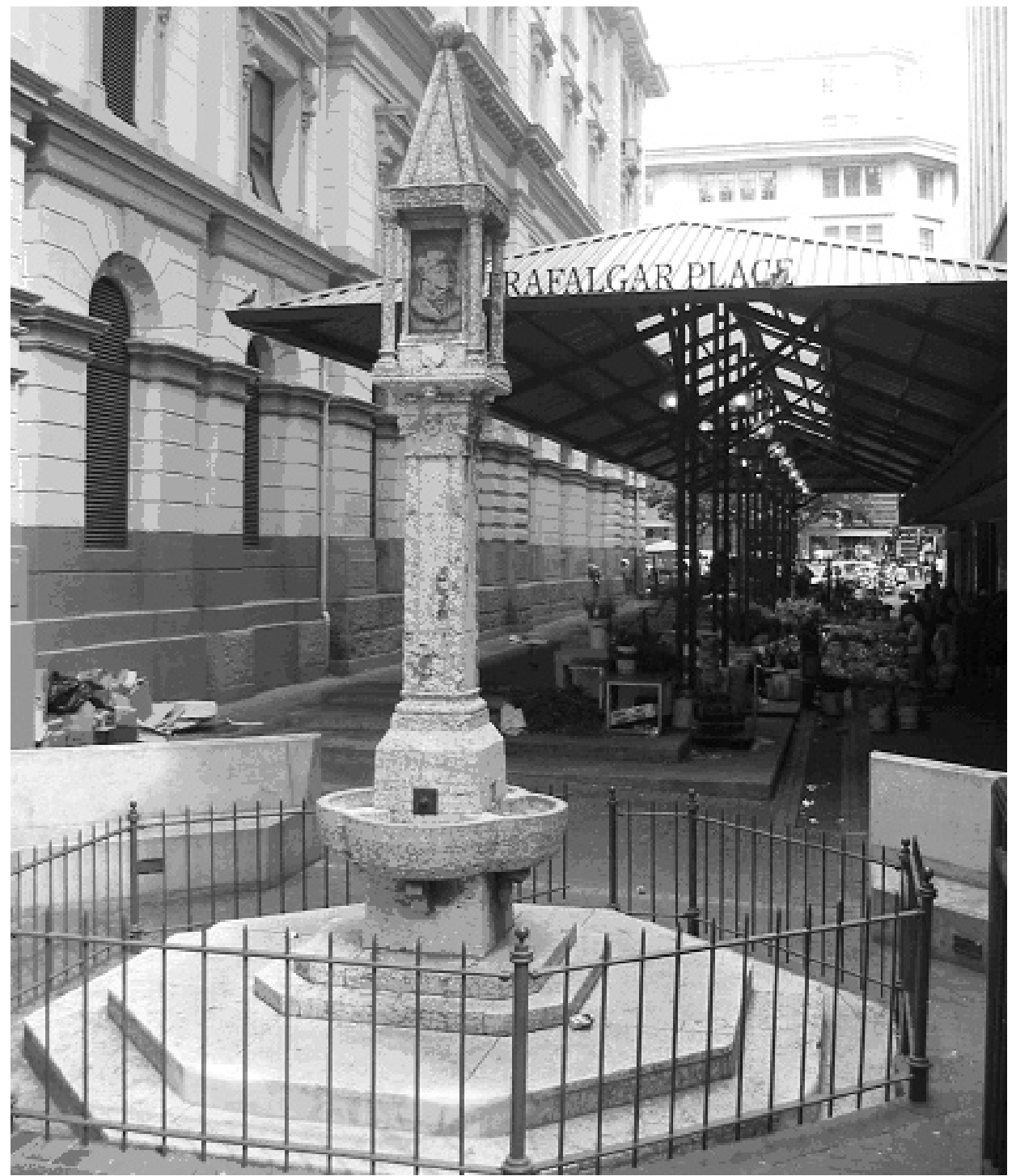

Illustration 5 Fountain from Cape Town (Source: P. Juuti). 
In Finland, Turku castle was founded at the mouth of the Aurajoki River in the 1280s. Finland was a part of Sweden from early 1200 s to 1809 and castles built in that era served the administrative purposes of the Swedish Crown. Turku castle was originally built in an open form of a fortified camp and the first well dates back to this era too. When the castle was extended, the kitchen was built around the well and it was kept in use. Up to this day its water is clear and of good quality and this well is considered to be the oldest remaining in Finland. In the early fpirteenth century, the fortified camp was built into a closed castle and then it was divided into a main castle and a bailey. (http://www.tkukoulu.fi/ tiimalasi/tl-rakennushist.html; Gardberg 1959, 7-8) In the mid-sixteenth century Turku castle was found to be old-fashioned, deteriorated and an inconvenient place in which to live. The castle was renovated into a handsome renaissance-style dwelling in 1556-1563 and extended to its current size. Water pipes made of lead and copper were installed from Kakolanmäki hill to the castle and this project took 4000 man-hours in 1561-63. Several more wells were also built to satisfy the increasing need for water. One of them, with timber frame and stone-lined walls is still to be seen in the courtyard (Stenroos \& al 1989, 60; Gardberg 1959, 309-310; http://www.nba.fi/fi/turun_linna; Puhakka \& Grönros 1995, 28-29; Gardberg 1961, 7-10). (Illustration 6)

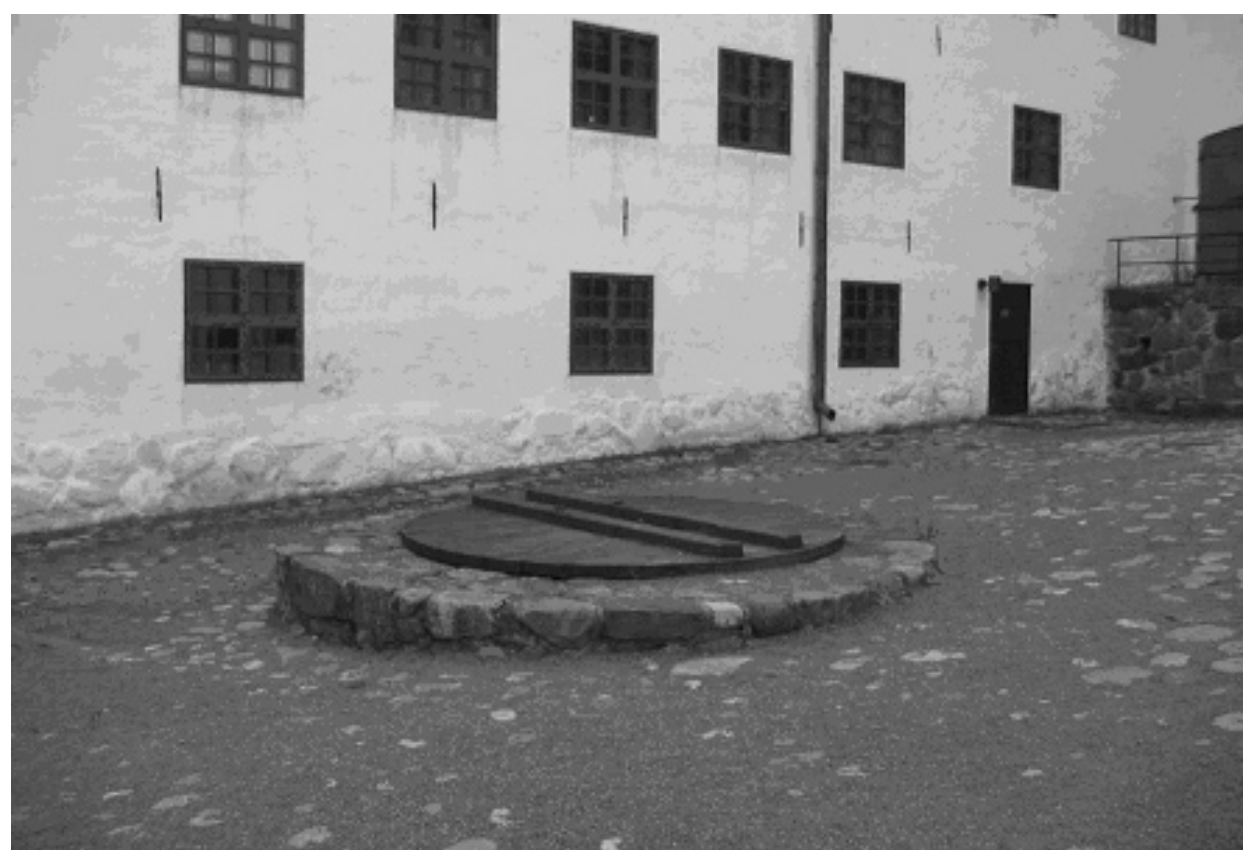

Illustration 6. Well from Turku Castle. (Source: P. Juuti)

Water also has a protective purpose in the castles in South Africa and Finland. The castle of the Cape of Good Hope has a moat that was finished 
shortly after 1720 and in Finland, for example, the safety of the Häme castle was increased in the $1770-80$ s by digging massive moats around the castle.

There were several toilets in Turku castle. From the fifteenth century onwards there were three: the privy in the gatekeeper's chamber (located in the corner of the gate tower), one in the prison and the third was located in the north wing. These three were connected to the same toilet drainage system and formed an independent system. The king, other noble residents and high officials had their own privies and one is still left in the medieval great hall. These privies were usually constructed on top of the corbels or supportive beams, a sort of a bay toilet, being located partially outside the wall. However, in the Turku castle, most of these privies in the quarters of the aristocracy were built completely inside the walls. The chamber of the young noblemen from the 1540s is located near the king's hall and it had access to the bay toilet (built on beams). Similar privies were attached to the castellan's chamber and the queen's hall (Puhakka \& Grönros 1995, 40, 48, 57, 59, 63, 75). None of these types of privies have survived to the present day; fires and time have taken their toll, but they can be seen in the scale model of the castle. However, other types of privies have been preserved quite well in this castle.

Ordinary soldiers did not have decent outhouses - in Finland, lakes and moats were used for this purpose as was the sea in South Africa, but at least later the commandant of the castle of Good Hope had a private toilet. Elsewhere in the old city of Cape Town wealthy people relied on water carriers and slaves to empty chamber pots. Lots of complaints were made that slaves did not do their job well in this regard. They should have emptied the buckets in the sea but instead they emptied them even in front of doors and into streets. Viktor de Klock describes this practice:

One of the most maddening habits of the slaves was that of emptying sanitary tubs into the canals, and frequently even before other people's doors, instead of into the sea" (cited in Fehr 1955, 13).

The fiscal and two burgher councillors acted twice a year as sanitary inspectors, but these inspections were only partly effective, since they were usually announced in advance and since the householder's responsibility was limited to seeing that the area immediately in front of his door was clean. (Shorten 1963, 54). It is easy to criticise such habits, but the task was not a pleasant one. It is likely that the adoption of new, improved techniques was slowed down by the fact that the owners did not have to do this duty themselves (Juuti \& Wallenius 2005, 136).

\section{Wells and toilets in the 1800 s}

The construction of a dug well requires planning and to some extent expertise in building. Walls are usually made of stone or wood. Wells with 
stone walls are typically round. Wooden walls for wells were traditionally built in a rectangular form (similar to the timber block construction for houses) and their shape was typically square. Dug wells are suitable in sand, gravel and moraine areas, where groundwater is closer to surface. The dug well is still the most common type used in the world. Its diameter varies usually between $1-5 \mathrm{~m}$ and the depth varies from a few metres to more than $20 \mathrm{~m}$. The best location for a dug well is on the lower slope of a ridge somewhat higher than the base (Juuti \& Wallenius 2005, 15).

At the end of 1800 s the water closet (WC) was considered an improvement that saved people from unpleasant tasks - such as emptying a chamber pot in the morning. But not everybody rushed to exploit this new invention. The wealthy burghers of Turku could hire people cheaply from the countryside and when there was a servant to empty the pots in the morning, there was no hurry to get a water closet, M. Brunow-Ruola explains. In these circles the WC and other facilities that eased everyday life were not acquired until the lady of the house was alone taking care of the household or had perhaps only one servant (Brunow-Ruola 2001, 234).

The most commonly used sources of water available to the inhabitants of Cape Town, prior to 1811, were springs on the slopes of Table Mountain or a fountain on the northern side of the Grand Parade. Another fountain was at the lower end of Caledon Square and was mainly for military use. In 1811 the Governor ordered iron pipes to be laid along the principal streets (Shorten 1963, 96-97). In 1834 there were 36 public fountains in the town area and it was reported that so much water was wasted from them that it would be advisable to erect public pumps (Report on Cape Town Water Supply by Chas. R Barlow, October 1914, 3/CT, 4/1/1/90, ref F134/4, in Cape Town Archives Depot).

Durban was established in 1835 by mostly British settlers in the middle of Nguni territory on the eastern coast of South Africa. Later on, Indian immigrants formed an important part of the town's population. There was plenty of water, but its quality was questionable. In 1854 Bishop Colenso complained that the water was the greater devil in Durban, because wells were not dug deep enough to keep organic material from polluting them. The only solution was to drink rainwater or the excellent water from the Umgeni River aboput $7 \mathrm{~km}$ away (Hattersley 1956, 96-97).

In 1856, the construction of an embankment at the head of the water above the Umgeni brickfields improved the sanitary condition of the town. (Ellis 2002, 38) The first wells in Durban were probably private; the earliest public well possibly dates from the year 1864. (Illustration 7) Its walls were made of alternate double rows of brick and single rows of slate. It was situated in Berea Road near the intersection with Old Dutch Road. The well was rediscovered in 1968 during excavations (Bjorvig 1994, 321-322). 


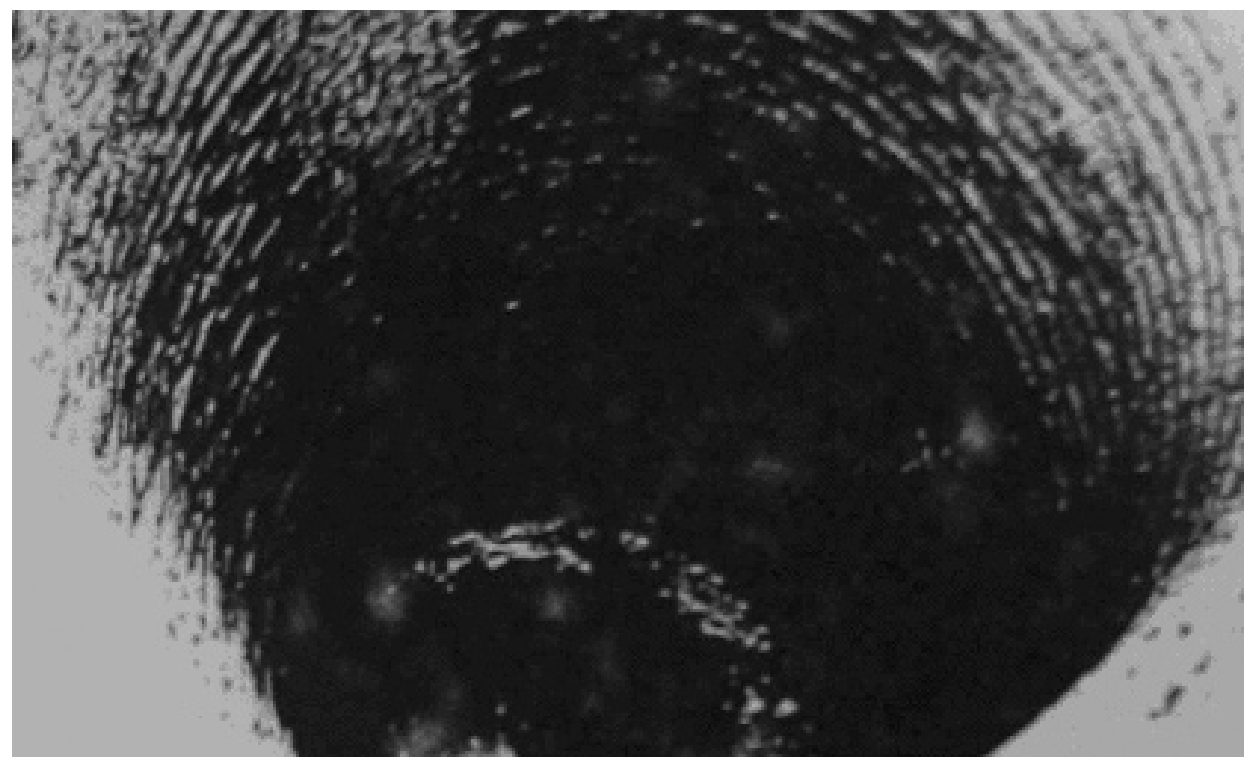

Illustration 7 Berea Road well from Durban. Source: Bjorvig.

Johannesburg was a sudden birth in the primarily rural South African Republic in 1886, after gold was discovered in the area. Its increasing cosmopolitan population and location of $70 \mathrm{~km}$ from the nearest major river created water supply problems from the start. Gold diggers used shallow wells, but the quality of their water was poor. Already in 1887, the state commissioned the Johannesburg Waterworks, Estates and Exploration Company to ease the problems (Hattersley 1973, 238).

Sanitation needed to be organised as well. At first 'sanitary gangs' were formed from convicts to empty cesspits. In 1888 the Sanitary Board imposed charges for the nightly collection of sanitary pails and for the daily collection of rubbish and slop-water. It was not allowed to run dishor bath water into the streets. Every house had a cistern in the back yard to collect such slop-water. A large wagon with several tanks came twice a week to empty these cisterns. Use of this service was compulsory and if left unpaid, it was punished by imprisonment (Hattersley 1973, 238; Leyds 1964, 32).

A British engineer, Robert Boyle, visited Johannesburg in 1890 and commented on the conditions there. He explained:

The sanitary condition of Johannesburg, though not yet all that could be desired, has been greatly improved within the last year or so [...] The pailcloset system is used. There is a splendid opening here for an improved dry-earth closet, as the system at present employed is very unsatisfactory (Sanitary Crusade, 20-21). 
At the end of the 1800s and the early 1900s the refuse problem of Johannesburg was worsening. In the Transvaal Law Reports several Supreme Court cases can be found dealing with these problems. For example, in 1907 in the case of Tobiansky vs. Johannesburg Town Council, it is apparent that there really was a serious problem with refuse and overall sanitary conditions in the town and especially in the township of Sophiatown. A portion of Waterval farm was used wrongfully [...] as a depositing site for night-soil, slop water and carcases of animals, and . . . consequently offensive, poisonous and unwholesome vapours and noxious matters issued and proceeded from the site and spread and were diffused [...] to properties, rendering them unwholesome, dirty and uncomfortable to live in [...] and seriously endangering [...] health (Transvaal Law Reports 1907, Tobiansky v. Johannesburg Town Council, p. 134-156).

The Waterval area was situated near a major public road, Old Krugersdorp Main Road. It was used for this purpose obviously since 1894 and became a serious health risk by 1907 . These practices and problems were common in the growing cities of the South Africa. (Transvaal Law Reports 1907...) Even on the other side of the world - in Tampere, Finland - similar cases were reported. (Juuti 2001, 66-87).

City fires were also a big problem. Before the time of waterworks, Finnish cities burned down frequently due to an insufficient amount of water and because of the dominant use of wood as a building material. In South Africa this problem was not as comprehensive as in Finland. There are however indications that Cape Town experienced numerous fires since the seventeenth century (Nikula 1972, 40-41; Worden et al 1998, 112).

\section{First WCs in South Africa and Finland}

The first reference to WCs in Cape Town is from the year 1814, when Lord Charles Somerset ordered four patented water closets for Government House at a cost of $£ 230$. They, however, did not become general, even in the larger residences, until the second half of the century (Hattersley 1973, 147).

In 1887, in Grahamstown, the old cesspool system was replaced by the pail system; at nights the sewage was emptied and removed to outside of the city, where it was covered up with soil (Souvenir of Grahamstown, 35, 39). A few years later, in 1891, Robert Boyle mentioned the use of pail-closet systems in Kimberley, Johannesburg, Pretoria and Durban. There were also plans for switching to water-borne sewerage system in Kimberley and Durban (Sanitary Crusade, 12, 20, 23 and 26).

Some progress was made in Durban in 1896, when an effective sewerage system became operational. Lavatories were provided throughout the town. There was also an outfall for waterborne household sewage, which was discharged during the first few years into the sea at the ebb tide (Bjorvig 1994, 327-328). In January 1906 there were problems with European-style water closets in Durban harbour. One of the disposal 
pipes was blocked and the plumber found two bottles, one shirt and two pair of socks inside. This led to investigations that involved the fort captain, harbour engineer, wharf master and even the water police. It is not known whether the offenders were found (Pietermaritzburg Archives Repository, NHD II/1/96 106/1906). A month later the same closet was under discussion again when the mechanical engineer proposed on 5 February that the iron seats should be replaced by wooden ones (Pietermaritzburg Archives Repository, NHD II/1/95 28/1906).

In Finland, sanitation problems were solved along with the water question. Water closets were seen as a solution to sanitation at the end of the nineteenth century. The first legally built water closet was completed in 1883 in the house of the Bank of Finland. Stockholm, in Sweden, got its very first water toilet the same year. In Finland a few 'illegal water closets' had been constructed even before that date. There was a heated discussion concerning the necessity of water toilets in Tampere and other cities in the late nineteenth century. At the time, a WC was built in most blocks of flats in Helsinki, but still in 1906 there were instances when outhouses were preferred (Katko 1996, 57-58; Nygård 2004, 224-225). The health board of Tampere demanded in 1890 that a WC, built in one of the downtown houses, should be dismantled, since it was illegal. The owner and builder of the toilet, F. W. Gustafsson, explained:

Closets $[\ldots]$ are equipped so that nothing but water can go through them to the city ditches, because there's a cesspool under the closet and there's a 4-inch $(10 \mathrm{~mm})$ diameter pipe with a filter (TKA, THL BI:1, Gustafsson 10.6.1890).

A similar incident occurred in Helsinki a decade earlier, when in 1882 a businessman, F. W. Grönqvist, had water closets put into his house. Two years later he lost a dispute with city officials, when the senate confirmed the decision of the provincial governor, which forbade the running of any impurities from closets to the sewer network (Laakkonen 2001, 48-50).

\section{Discussion and Conclusions}

Today, there are several pressing environmental issues in South Africa and Finland in respect of water issues. There is a lack of natural water resources. This requires extensive water conservation and control measures. Growth in water use is much faster than the available, and also the anticipated future supply. There is the severe pollution of rivers as a result of agricultural, industrial and domestic discharges. Air pollution is resulting in acid rain. There are many examples of soil erosion and desertification is still the order of the day. Both South Africa and Finland have to cope with these problems simultaneously.

The greatest challenge now in Finland is to find a solution for complying with new wastewater treatment regulations in areas of scattered 
settlements. The best choice might be the complete recycling of nutrients, which requires replacing the water toilet by the compost toilet with urine separation and a significant change of attitude. The second-best solution would be leading the wastewater to the sewerage works, but long distances make this almost impossible. Finland has plenty of water, so there's no need for two-pipe systems, where for example the flushing water is of lower quality. Rural areas without sewer networks should seriously consider abandoning the flushing toilet altogether. In urban areas, with established networks, it is not reasonable to replace the existing infrastructure with a new system. In general, the large wastewater treatment plants work well. But for new areas the system based on composting toilets should be studied and developed further.

In 2004, Transparency International (2001: www.gwdg.de/ uwvw/icr. $\mathrm{htm}$ ) ranked Finland - again, the fifth time in a row - as having the lowest perception of corruption in the world. Also South Africa made out very well in this evaluation, it was second in Africa. It's not co-incidental that the most corrupt countries - without pointing a finger directly at them - are also the countries with the worst water governance.

Outhouses and wells remained in use in cities for some time after the establishment of central water supply systems. Water and sanitation services reached the suburban areas slowly and in some areas of scattered settlements they still are not available. So in 2004, 650000 private wells (500 000 simple dug wells and 100000 artesian wells) remain in Finland and the majority - probably two-thirds - require immediate maintenance to improve the quality of the water. These figures include both the main households and the holiday homes. But a little over 90 per cent of all Finns get water of good quality from local waterworks distributed to their permanent address. In South Africa, the backlog in supplying people with access to safe drinking water is a national priority and scheduled to be eliminated in 2008 (http://www.info.gov. $\mathrm{za} / \mathrm{speeches} / 2004 / 04051015151001 . \mathrm{ht})$.

The conditions have not always been as good and surprises may occur. But all in all, the situation is quite good in both countries. In Finland in the early $2000 \mathrm{~s}$ the waterworks provided $250 \mathrm{l} \mathrm{p} / \mathrm{d}$ per capita for private use. For industrial purposes, the figure is $20000 \ell$, but industry gets only a small amount of its water from public waterworks. The total consumption of communities and industry is 7,5 per cent of the renewable water resources. There are even in suburban areas 40000 people and in sparsely populated areas more than half a million people who remain outside the water supply network. Approximately 300000 people have some impurities in their domestic water and one million people living in houses have their own sewer systems, without a connection to a municipal sewer system. 
The reason for this favourable situation in both countries is that the right choices were made in the past. The nineteenth century was a time of increasing environmental problems in Finnish and South African cities. Old water supply systems became inadequate when the population increased. The contemporary term for the situation was the water question' - nowadays it is called the 'water issue' - and the answer to the issue was sought for decades. Developing countries of our time confront this same acute problem.

Water management, i.e. water supply and sewerage and waste management, are essential elements of the development of communities. Together they are called environmental services. The environmental services are justified in themselves and by expecting direct and indirect benefits. The concrete infrastructure is the basis for economic and social systems, which can be vulnerable to environmental changes. The success of urbanization and the modernization of the rural areas are closely connected to finding solutions for environmental services. A well and an eco-toilet in areas with scattered settlements will provide in future ecological solutions. Investing in water supply and sewers is always worthwhile.

Water supply and sewerage are vital, although mainly invisible, parts of the economic-technical infrastructure of a community. Environmental services are essential for public health, hygiene, the protection of the environment and industry. Water supply and sanitation, sewerage and waste management are the basic issues of environmental history and studying them can give new ideas for surviving the problems caused by increasing standards of living and populations. The solution for environmental services is simultaneously a solution to the problem of how to live and settle successfully, as well as how to create better surroundings. Wells and toilets are an essential part of durable solutions for the future. 


\section{References}

Archival Sources

South African National Archives

Cape Town Archives Depot

Town Clerk, Cape Town (3/CT)

$4 / 1 / 1 / 90$

Pietermaritzburg Archives Depot

Natal Harbour Department (NHD)

$$
\begin{aligned}
& \text { II / 1/95 } \\
& \text { II/ 1/96 }
\end{aligned}
$$

Tampere City Archives (TKA):

Health board (THL), BI:1

\section{Literature}

Anon, A Sanitary Crusade through South Africa. Reprinted from "The Building News," June $26^{\text {th }}$ and July $3^{\text {rd }}$, 1891. London: Robert Boyle \& Son, Limited 1891.

Anon., South Africa Yearbook 2003/2004. Pretoria: Government Communications 2004.

Anon., Souvenir of Grahamstown: A Health and Holiday Resort. Grahamstown: Guest and Son 1887.

Brunow-Ruola, M., Helene ja Augusta. Porvariston elämää Turussa 1870-1920. (Life of Bourgeoisie in Turku). Keuruu: Otava 2001.

Ellis, B., 'White Settler Impact on the Environment of Durban, 1845-1870', in South Africa's Environmental History: Cases \& Comparisons, ed. by Stephen Dovers et al. Cape Town: David Philip publishers 2002 .

Fehr, W., The Old Town House, Its Place in the History of Cape Town. Cape Town: Cape Times 1955.

Gardberg, C.J., Åbo slott under den äldre Vasatiden. (Åbo Castle under the Older Vasa Times). Helsinki: Suomen Muinaismuistoyhdistys 1959.

Gardberg, C.J., Turun linna ja sen restaurointi. (Turku Castle and its Restoration). Turku: Turun kaupunki 1961.

Hattersley, A.F., More Annals of Natal. London: F. Warne \& Co 1936.

Hattersley, A.F., An Illustrated Social History of South Africa. Cape Town: A.A. Balkema 1973. 
Juuti, P., Kaupunki ja vesi. (City and Water). Doctoral dissertation. Acta Electronica Universitatis Tamperensis 141. Tampere: Kehrämedia Inc 2001.

Juuti, P.S. \& Wallenius, K.J., Brief History of Wells and Toilets. Pieksämäki: Kehrämedia Inc 2005.

Katko, T., Maaseudun vesihuollon kehittyminen Suomessa: suuntaviivoja kehitysmaille? Taustaselvitys. (Development of the Water Supply in Countryside of Finland: Guidelines for Developing Countries?). TTKK, VYT B 35, 1988.

Katko, T., Vettä! - Suomen vesihuollon kehitys kaupungeissa ja maaseudulla. (Water! - Evolution of Water Supply in Finnish Towns and Countryside). Tampere: Vesi- ja viemärilaitosyhdistys 1996,

Laakkonen, S., Vesiensuojelun synty. Helsingin ja sen merialueen ympäristöhistoriaa 1878-1928. (The Birth of Water Protection. Environmental History of Helsinki and its Sea Area). Tampere: Gaudeamus 2001.

Leyds, G.A., A History of Johannesburg. Johannesburg: Nasionale Boekhandel Beperk 1964.

Mattila, H., Appropriate Management of On-Site Sanitation. Doctoral dissertation. Tampere University of Technology, Publication 537. Tampere 2005.

Myllyntaus, T., "Foreword", pp. 7-14 in Juuti, P. \& Katko, T., From a Few to All-Long-term development of water and environmental services in Finland. Pieksämäki: Kehrämedia Inc 2004.

Nikula, O., Turun kaupungin historia 1809-1856. (History of the City of Turku). Turku: Turun kaupunki 1972.

Nygård, H., Bara et ringa obehag? Avfall och renhållning i de finländska städernas profylaktiska strategier 1830-1930. (Only a Slight Annoyance? A Prophylactic Perspective on Sanitary Services in Finland). Åbo: Åbo Akademi 2004.

Pajula, H. \& Triipponen, J-P. (eds.), Selvitys Suomen kastelutilanteesta, esimerkkialueena Varsinais-Suomi. (Research of Watering Situation of Finland Taking Varsinais-Suomi Area as an Example). Series Suomen ympäristö, 629, Helsinki 2003, in: http://www. ymparisto.fi/download.asp?contentid=3878\&lan=FI

Paulaharju, S., Asuinrakennuksia Uudella kirkolla Viipurin läänissä. (Dwelling-houses in Uusikirkko in Viipuri Area). Helsinki 1906.

Paulaharju, S., Kainuun mailta. Kansantietoutta Kajaanin kulmilta. (From the Kainuu. Folk Wisdom from the Kajaani Area). Porvoo: WSOY 1958. 
Puhakka, M. \& Grönros, J., Turun linna. (Turku Castle). Jyväskylä: Turun Maakuntamuseo 1995.

Shorten, J.R., Cape Town. [Cape Town: John R. Shorten (pty.) Limited 1963]

Stenroos, M.\& al, Turkulaisen veden pitkä matka Halistenkoskelta Turun keskuspuhdistamolle. (Long Journey of Turku Water from Halistenkoski to Turku Central Purificator). Turku: Turun Vesilaitos 1989.

Syvänne, I., The Age of Hippotoxotai. Art of War in Roman Military Revival and Disaster (491-636). Acta Universitatis Tamperensis; 994. Tampere 2004.

Transvaal Law Reports 1907, Tobiansky v. Johannesburg Town Council.

Van der Merwe, P.J., Trek - Studies oor die Mobiliteit van die Pioniersbevolking aan die Kaap. (Trek - Studies regarding the mobility of the pioneers at the Cape.) Kaapstad: Nasionale Pers $1945 a$.

Van der Merwe, P.J., Pioniers van die Dorsland. (Pioneers of the Thirstland). Kaapstad, 1945b.

Van der Waal-Braaksma, G. and Ferreira, O.J.O., Die Noordweste. (The North-West.) Johannesburg: Genootskap vir Afrikaanse Volkskunde 1986.

Walton, James, Water-mills, windmills and horse-mills of South Africa. Cape Town: C. Struik 1974.

Wijmer, S., Water om te drinken. VEWIN, the Netherlands. 1992.

Worden, N, van Heyningen, E. \& Bickford-Smith, V., Cape Town: The Making of the City. An Illustrated History. Claremont: David Philip Publishers 1998.

\section{Article Sources}

Archer, S., 'Technology and ecology in the Karoo: A Century of Windmills, Wire and Changing Farming Practice', Journal of Southern African Studies, vol. 26, No. 4 (Dec., 2000), 675-96.

Lawrence, P., Meigh, J. and Sullivan, C., The Water Poverty Index: An International Comparison. Http://econwpa.wustl.edu:8089/eps/ $\mathrm{dev/papers/0211/0211003.pdf}, 25.5 .2005$.

Salonen, V.P., Mapping of groundwater reserves in Finland: the present status and aspects for future work. Http://www.isgs.uiuc.edu/ 3DWorkshop/2002workshop/salonen.do, 5.5.2005. 
Werz, B.E.J.S., 'Survey and excavation of the main well in Cape Town Castle, South Africa: fieldwork and structural aspects', The International Journal of National Archaeology, 31, 1 (2002), 89-98.

\section{Unpublished}

Bjorvig, A.C., Durban 1824-1910: the formation of a settler elite and its role in the development of a colonial city. Ph.D. thesis, University of Natal, 1994.

Haarhoff, J. \& Tempelhoff, J., Water supply to the Witwatersrand: 1924-2003. Flows From the Past-Conference paper, Vereeniging, December 2004.

Honkavirta, H., Maanviljely-ympäristö fysiikan opetuksen lähtökohtana. Perunan ja nurmen viljelyn mekaniikka ja lämpöoppi. (Farming Surroundings as a Starting Point for Physics Teaching. Mechanics and Thermodynamics of Potato and Grass Cultivation). Master thesis, University of Helsinki, 1998.

\section{Webliography}

Http:/ / earthtrends.wri.org/country_profiles/index.cfm?theme $=2$, 1.5.2005

Http://igrac.nitg.tno.nl/system.html, 1.5.2005.

Http://www.africaguide.com/facts.htm, 12.5.2005.

Http://www.dwaf.gov.za/Documents/Policies/NWRS/Sep2004/pdf/

Chapter2.pdf, 2.5.2005.

Http://www.dwaf.gov.za/Geohydrology/Databases/databases.htm, 5.5.2005.

Http://www.gwdg.de/ uwvw/icr.htm, 1.5.2005.

Http://www.info.gov.za/speeches/2004/04051015151001.ht, 25.5.2005.

Http://www.nba.fi/fi/turun_linna, 12.5.2005.

Http://www.statoids.com, 1.5.2005.

Http://www.tkukoulu.fi/tiimalasi/tl-rakennushist.html, 12.5.2005.

Http://www.unesco.org/water/wwap/wwdr/table_contents.shtml, 1.5.2005.

http://zar.co.za/world.htm, 20.6.2005 




